\title{
REFLETINDO SOBRE A NOVA E VELHA FAMÍLIA
}

Maria Lúcia Boarini

\begin{abstract}
(...) as características mais pessoais e particulares da vida intima do individuo permanecem obscuras, somente se tornando sinais significativos quando são remetidas à origem no corpo medicamente significante da família. Logo a família é o segredo do individuo (Pôster, 1979, p. 22).
\end{abstract}

Dentre os animais existentes e conhecidos sobre a face da Terra, o homem é o mais dependente ao nascer. Nesta situação, necessariamente deve ser alimentado, higienizado, aquecido, afagado, enfim depende de outros para alcançar as mínimas condições para manter-se vivo. Porém, tratando-se da espécie humana, não basta estar vivo. Ao entrar no mundo, o homem se introduz em uma organização social nutrida pelas mais variadas necessidades e simbolismos, o que o coloca em contínua e indefinida dependência do outro. Mais que isso, se comparadas a uma rede rodoviária, as relações humanas não são vias de mão única, pelo contrário, são um complexo de caminhos pavimentados de parcerias, conflitos, paixões, angústias, contradições, embates e daí por diante. Como diria Voltaire (1694-1778), "O homem entra em guerra, ao entrar no mundo". É nesta "guerra" que se consolida a intersecção entre o desenvolvimento do indivíduo, o grupo social e a forma de produção e organização da sociedade.

O primeiro grupo ao qual o ser humano pertence, convencionalmente denominado família, é algo muito velho e, paradoxalmente, muito novo. É um conceito velho se considerarmos que o homem, invariavelmente, em seus primeiros anos de vida, vai necessitar dos cuidados alheios, e qualquer que seja o vínculo (de consangüinidade, de filantropia etc.) que o prende aos adultos circundantes, deve contar com alguém ou com um grupo de pessoas que lhe ofereça os cuidados necessários para sua sobrevivência. É um conceito permanentemente novo, à medida que a família vai se transformando e remodelando-se de acordo com os contornos da sociedade na qual esta inserida.

Trocando em miúdos - reconhecemos que estamos simplificando a análise - diremos que na sociedade burguesa o sangue e a habitação em comum constituem-se em características determinantes da formação da família, cujos membros, via de regra, são constituídos de pai, mãe e filhos. A união entre o homem e a mulher é selada como eterna ou até a morte, e sua finalidade principal é a reprodução. A manutenção deste grupo é realizada pelo pai, provedor financeiro, e a mãe, provedora dos cuidados domésticos.

Ora, temos que reconhecer que atualmente, no Mundo Ocidental, do qual podemos fazer afirmações com certa segurança, esta formatação já ganhou outros contornos. Senão vejamos.

Em nossos dias, pelo menos no Brasil, a necessidade tem levado a mulher a se introduzir no mercado de trabalho, o que lhe conferiu importante papel no provimento financeiro da família, não sendo raros os casos em que é a única provedora. Tal fato, por sua vez, vem promovendo o afastamento precoce dos filhos do convívio familiar, e assim o processo de socialização da criança está cada vez mais terceirizado (creches, escolas, natação, inglês, informática ...). Neste sentido, constatamos também a necessidade de limitação do número de filhos, tornada possível pelo desenvolvimento de métodos contraceptivos cada vez mais seguros, o que, por sua vez, possibilita a desvinculação entre sexualidade e procriação. Na perspectiva sociológica, temos o prestígio crescente dos valores individualistas, que têm favorecido "o viver só". Desta forma não é raro mães e pais solteiros ou separados que assumem a responsabilidade dos cuidados com os filhos. Outrossim, graças aos avanços da medicina em relação à longevidade, vivemos uma outra situação raramente encontrada em décadas passadas: os avós (ou mesmo apenas um deles) vivendo só e regularmente (na melhor das hipóteses) recebendo a visita de seus familiares. No campo das possibilidades cientificas temos, ainda, a fertilização e reprodução assistida, que pode favorecer a reprodução sem o menor contato entre os progenitores e, mais que isso, favorece o aparecimento das 
"barrigas de aluguel" ou do banco de sêmen. No campo jurídico temos a legalização do divórcio, o reconhecimento das relações homossexuais. Enfim a formatação da família passa por um precipitado processo de transformações de toda ordem, e seguir nesta discussão é tarefa para um cuidadoso estudo sociológico, que este espaço não comporta.

Com estas pontuações pretendemos, apenas, estimular o debate sobre a instituição família, que, apesar de multimilenar, apresenta-se sempre com novas roupagens, em atendimento à demanda da sociedade da qual é o núcleo, o que a faz sempre nova na forma de constituir-se, na sua configuração e na sua dinâmica interior. É neste ponto, em nosso entender, que reside um dos pivôs da crise de paradigmas que vivemos na atualidade. Cobram-se da família responsabilidades que ela não tem mais condições de assumir. Um exemplo bastante corriqueiro em nossos dias é a cobrança das escolas quanto à participação dos pais nas tarefas de casa dos filhos. Principalmente no Ensino Fundamental, a instituição escolar atribui àqueles o não-aproveitamento ou o baixo rendimento escolar do filho/aluno. Em geral, delega-se à família a função de redentora de tantas e tão preocupantes mazelas sociais. E isto é amplamente divulgado por todos os meios de comunicação. E mais: em geral conta com a anuência de grande parte da população, que não se detém para questionar qual a família que temos em mente.

Enfim, Psicologia em Estudo reúne neste número especial alguns estudos que, seguramente, vão nos auxiliar a rever o nosso conceito sobre família. Os artigos aqui publicados, resultantes de cuidadosos estudos acadêmicos, certamente nos chamam a atenção para alguns dos modernos arranjos familiares e, nesta direção, favorecem a ampliação dos nossos limites de interpretar e analisar a "nova" família do Mundo Ocidental, no século XXI.

\section{REFERÊNCIAS}

Poster, M. (1979). Teoria crítica da família. (Trad. Álvaro Cabral). Rio de Janeiro: Zahar Editores. 